\title{
Combination therapy with rituximab and cyclophosphamide in the treatment of anti- neutrophil cytoplasmic antibodies (ANCA) positive pulmonary hemorrhage: case report
}

\author{
Emily M Baird ${ }^{1 *}$, Thomas JA Lehman² and Stefan Worgall ${ }^{3}$
}

\begin{abstract}
Anti-neutrophil cytoplasmic antibody (ANCA)-associated vasculitis (AAV) with pulmonary hemorrhage is rare in childhood. Standard treatment includes corticosteroids and cyclophosphamide (CYC), which is associated with a high level of toxicity. We report a white female with ANCA positive pulmonary hemorrhage who was treated with cyclophosphamide (CYC) and rituximab (RTX) combination therapy.
\end{abstract}

\section{Background}

AAV with pulmonary hemorrhage is rare in childhood. Untreated AAV with pulmonary hemorrhage is associated with a 2 year mortality rate in excess of $90 \%$ [1]. Standard treatment with a corticosteroid may be associated with medication related complications. We present a case of recurrent pulmonary hemorrhage associated with antineutrophil antibody (ANCA)-associated vasculitis (AAV) in childhood. Treatment with cyclophosphamide (CYC) and rituximab (RTX) produced a prompt and sustained remission, and she was able to discontinue steroid therapy.

\section{Case Presentation}

$\mathrm{BH}$, a white female, presented at 7 years of age with fever, cough and respiratory distress following Streptococcal pharyngitis. Her chest radiograph revealed bilateral patchy infiltrates. She was hospitalized with hypoxemia and hypercapnea and required intubation and mechanical ventilation for 14 days. Her endotracheal tube secretions were noted to be bloody and her hemoglobin fell from 10.6 to $8.5 \mathrm{~g} / \mathrm{dl}$ within 24 hours following admission. The Indices of Coagulation were normal and she was negative for antibodies to anti-nuclear antibody (ANA) and glomerular basement membrane; in addition, protease 3 and

\footnotetext{
* Correspondence: bairdem@hss.edu

'Hospital for Special Surgery, New York, NY and Weil Medical Center, New York, NY, USA

Full list of author information is available at the end of the article
}

myloperoxidase were both negative. There was no hematuria, and C-reactive protein (CRP) was elevated at 12.28 $\mathrm{mg} / \mathrm{dL}, 8.66 \mathrm{mg} / \mathrm{dL}$, and $10.11 \mathrm{mg} / \mathrm{dL}$. A tracheal culture grew Pseudomonas, and chest radiographs showed diffuse airspace opacities with a small right pleural effusion. She was treated with surfactant and dexamethasone, as well as epinephrine and helium in the inspired gas and $17 \mathrm{mg}$ of parenteral methylprednisolone every 6 hours for 14 days. Following a blood transfusion, she slowly stabilized with supportive care and was discharged after eighteen days. Pulmonary hemorrhage was suspected, but a bronchoscopy was refused.

One month after discharge, she complained of rhinorrhea, congestion, cough, stomach pain, and vomiting.

Three months later, she again had Streptococcal pharyngitis. She underwent an elective bronchoscopy to assess for residual pulmonary hemorrhage. The bronchoscopy showed no active bleeding, though subsequently she had an acute $\mathrm{PH}$ episode during the bronchoscopy and again required mechanical ventilation. There was no hematuria. Her CRP was $20.40 \mathrm{mg} / \mathrm{dL}$, and she had a positive Epstein-Barr varius titer of 1:160. Her chest computed tomography scan revealed bilateral infiltrates (Figure 1). She was treated with dexamethasone and vasopressors. She again required a blood transfusion. Her symptoms improved, and she was discharged on $1 \mathrm{mg} / \mathrm{kg}$ daily of prednisolone after 8 days. 


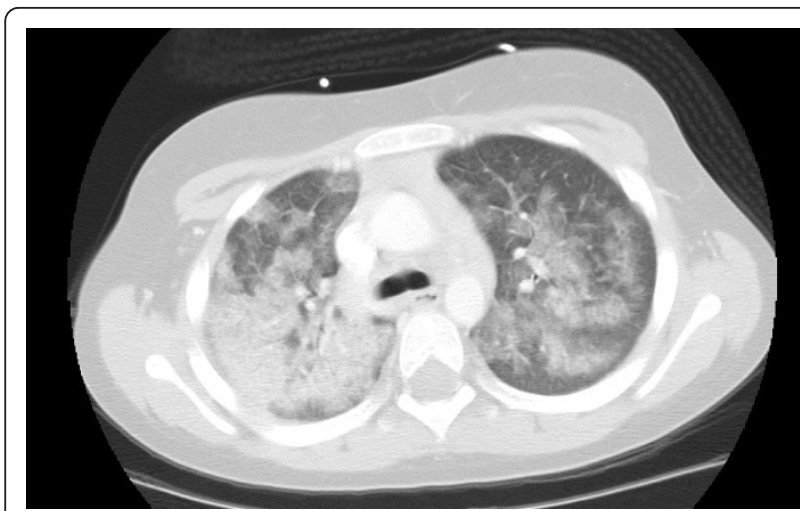

Figure 1 CT scan at the carina level of the lung showing hemorrhage during the second admission.

She was treated for 2 months with prednisolone 30 $\mathrm{mg}$ daily and subsequently tapered to $7.5 \mathrm{mg}$ every other day. Chest radiographs continued to show bilateral patchy infiltrates, and she had periodic hemoptysis. The reticulocyte count peaked at 5.96 with a hemoglobin of 13.6, 15 months after discharge. Her prednisone dose was increased to $15 \mathrm{mg}$ daily in response to continued bilateral infliltrates on radiograph and reticulocytosis.

Almost 3 years later, at 10 years of age, a chest radiograph showed worsening diffuse airspace opacities, pulmonary interstitial emphysema, and a pneumo-mediastinum following Streptococcal pharyngitis. She again required admission and mechanical ventilation for pulmonary hemorrhage and respiratory failure. During this admission she tested positive for ANCA Myloperoxidase antibodies by indirect fluorescent antibody assay at 130 $\mathrm{AU} / \mathrm{mL}$ and $99 \mathrm{AU} / \mathrm{mL}$ (Figure 2), with persistently negative ANA and anti glomerular basement membrane antibody. There was no hematuria. The patient had an elevated CRP of $11.75 \mathrm{mg} / \mathrm{dL}$ during admission. She was treated with vasopressors and $25 \mathrm{mg}$ of perenteral methylprednisolone every 6 hours. She was intubated for 12 days. Her symptoms improved, and she was discharged after nineteen days on prednisolone of $1 \mathrm{mg} / \mathrm{kg}$ daily.

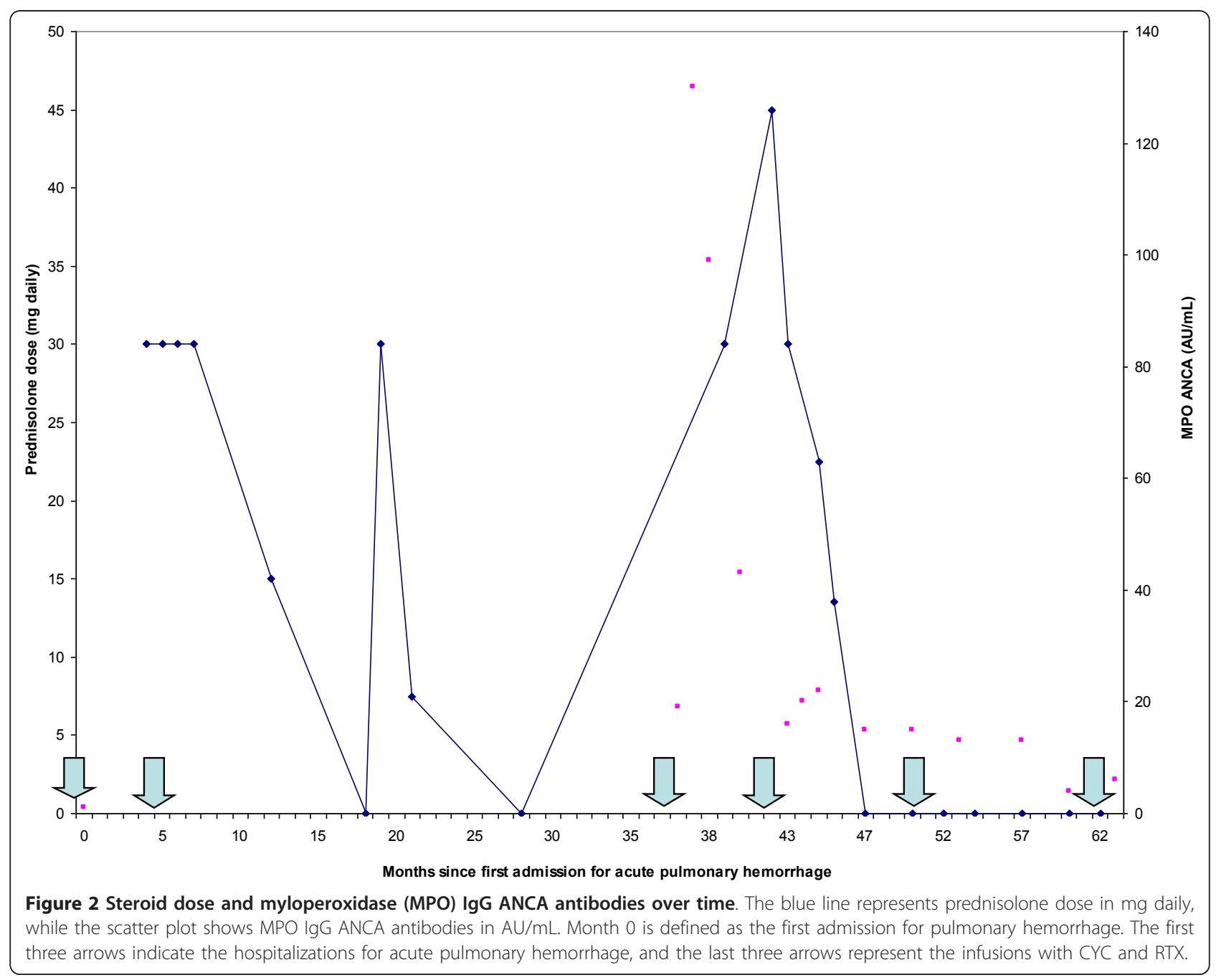


Because she had recurrent episodes of life threatening pulmonary hemorrhage despite 3 years of chronic steroid administration, we elected to treat her aggressively for AAV at 10 years of age. At the time of the first infusion, she was being treated with $45 \mathrm{mg}$ daily of prednisolone. After appropriate discussion of the risks and benefits, consent was obtained and she was hospitalized for CYC and RTX treatment $\left(750 \mathrm{mg} / \mathrm{m}^{2}\right.$ of CYC and $600 \mathrm{mg} / \mathrm{m}^{2}$ of RTX with a maximum of $1000 \mathrm{mg}$ ). Following this therapy she was discharged on prednisolone of $30 \mathrm{mg}$ daily which was tapered off gradually over five months. Six and eighteen months after the first infusion, she was retreated with the same dose of CYC and RTX. She tolerated the treatment well. There were no recorded infections or leucopenia. The patient's CRP and reticulocyte count have normalized; the most recent CRP was $0.53 \mathrm{mg} / \mathrm{dL}$. There have been no further episodes of pulmonary hemorrhage, and she remains well without corticosteroid therapy two years following her last infusion.

\section{Discussion}

Diagnosis of AAV was made according to definitions of the Chapel Hill Consensus Conference. The persistently elevated reticulocyte count prior to CYC/RTX therapy suggested that our patient's bleeding was a chronic process. Conventional treatment for this chronic condition includes 3 years of CYC and corticosteroids [2,3].

RTX has recently been investigated as an alternative treatment for AAV [4-8], but two recent studies of RTX in AAV found no clear superiority to CYC $[7,9]$. The combination of CYC and RTX has been used in an adult with pulmonary hemorrhage secondary to SLE [10]., and we have used it extensively in childhood rheumatic diseases [11-13]. We therefore hypothesized that it might be helpful in our patient with AAV-associated pulmonary hemorrhage. This treatment was given to achieve remission. Alternative therapies of uncertain benefit in this setting might include plasma exchange [14,15], as well as azathioprine or mycophenolate mofetil [16].

\section{Conclusions}

Our patient's remission suggests that combination therapy with CYC and RTX may be effective in this condition. Further studies of the efficacy of this therapy in the treatment of AAV are needed.

\section{Consent}

A waiver of informed consent and waiver of Health Insurance Portability and Accountability Act authorization have been obtained through the local Institutional Review Board.

\section{Abbreviations}

ANCA: anti-neutrophil cytoplasmic antibody; AAV: anti-neutrophil cytoplasmic antibody (ANCA)-associated vasculitis; CYC: cyclophosphamide; RTX: rituximab; ANA: anti-nuclear antibody; CRP: C-reactive protein; $\mathrm{m}^{2}$ : square meter; g: gram; mg: miligram; dL: deciliter; PH: pulmonary hemorrhage; kg: kilogram; SLE: systemic lupus erythematosus; MPO: myeloperoxidase; IgG: Immunoglobulin G.

\section{Acknowledgements and Funding}

There was no additional funding required for this case report.

\section{Author details}

${ }^{1}$ Hospital for Special Surgery, New York, NY and Weil Medical Center, New York, NY, USA. ${ }^{2}$ Hospital for Special Surgery, New York, NY and Cornell University, New York, NY, USA. ${ }^{3}$ Cornell University, New York, NY, USA.

\section{Authors' contributions}

EB wrote the initial manuscript draft. SW assisted in the acquisition of data. All authors reviewed and revised drafts. TL was involved in the interpretation of data and gave approval for the final version to be published. All authors read and approved the final manuscript.

\section{Competing interests}

The authors declare that they have no competing interests.

Received: 24 June 2011 Accepted: 27 October 2011

Published: 27 October 2011

\section{References}

1. Hoffman GS, Kerr GS, Leavitt RY, Hallahan CW, Lebovics RS, Travis WD, Rottem M, Fauci AS: Wegener's granulomatosis: An analysis of 158 patients. Ann Intern Med 1992, 116:488-498.

2. Mukhtyar C, Guillevin L, Cid MC, EUL Dasgupta B, de Groot K, Gross W, Hauser T, Hellmich B, Jayne D, Kallenberg CG, Merkel PA, Raspe H, Salvarani C, Scott DG, Stegeman C, Watts R, Westman K, Witter J, Yazici H, Luqmani R, European: AR recommendations for the management of primary small and medium vessel vasculitis. Ann Rheum Dis 2009, 68:310-317.

3. de Groot K, Harper L, Jayne DRW, Flores Suarez LF, Gregorini G, Gross WL, Luqmani R, Pusey CD, Rasmussen N, Sinico RA, Tesar V, Vanhille P, Westman K, Savage CO, EUVAS (European Vasculitis Study Group): Pulse versus daily oral cyclophosphamide for induction of remission in antineutrophil cytoplasmic antibody-associated vasculitis: a randomized trail. Ann Intern Med 2009, 150:670-680.

4. Chen M, Kallenberg CG: ANCA-associated vasculitides-advances in pathogenesis and treatment. Nat Rev Rheumatol 2010, 6(11):653-64, Epub 2010 Oct 5.

5. Niles J: Rituximab in induction therapy for anti-neutrophil cytomplasmic antibody (ANCA) vasculitis. Clin Exp Immunol 2011, 164(Suppl 1):27-30.

6. Geetha D, Seo P, Specks U, Fervenza FC: Successful induction of remission with rituximab for relapse of ANCA-associated vasculitis post-kidney transplant: report of two cases. Am J Transplant 2007, 7(12):2821-5, Epub 2007 Oct 1.

7. Stone JH, Merkel PA, Spiera R, Seo P, Langford CA, Hoffman GS, Kallenberg CG, St Clair EW, Turkiewicz A, Tchao NK, Webber L, Ding L, Sejismundo LP, Mieras K weitzenkamp D, Ikle D, Seyfert-Margolis V, Mueller M, Brunetta P, Allen NB, Fervenza F, Geetha D, Keogh KA, Dissin EY, Monach PA, Peikert T, Stegemen C, Ytterberg SR, Specks U, RAVE-ITN Research Group: Rituximab versus cyclophosphamide for ANCAassociated vasculitis. N Engl J Med 2010, 36393:221-32.

8. Keog KA, Ytterberg SR, Fervenza FC, Carlson KA, Schroeder DR, Specks U: Rituximab for refractory Wegener's granulomatosis: report of a prospective, open-label pilot trial. Am J Respir Crit Care Med 2006, 173(2):180-7.

9. Jones BRachel, Jan Willem Cohen Tervaert, Hauser Thomas, Lugmani Raashid, Morgan DMatthew, Au Peh Chen, Savage OCaroline, Segelmark Marten, Tesar Vladimir, van Paassen Pieter, Walsh Dorothy, Walsh Michael, Westman Kerstin, Jayne RWDavid, the European Vasculitis Study Group: Rituximab versus Cyclophosphamide in ANCA-Associated Renal Vasculitis. The New England Journal of Medicine 2010, 363:211-220. 
10. Narshi BChetan, Haider Seema, Ford MCharlotte, Isenberg ADavid, Giles Plan: Rituximab as early therapy for pulmonary haemorrhage in systemic lupus erythematosus. Rheumatology 2010, 49(2):392-394, Epub 2009 Nov 19.

11. Barillas L, Adams A, Angeles ST, MacDermott EJ, Barinstein L, Lehman TJA: Combination Cyclophosphamide and Rituximab for the Treatment of Childhood Onset SLE. Arthritis and Rheumatism 2006, 54(suppl):S689-90

12. Lehman TJA: Lupus Nephritis Treated With Cyclophosphamide and Rituximab: A Case Study. Lupus Foundation of America, Inc .

13. Adams A, Barillas-Arias L, Angeles ST, MacDermott EJ, Barinstein L, Lehman TJA: Cyclophosphamide and Rituximab Combination Therapy for the Treatment of Juvenile-Onset Scleroderma: 6 Patient Case Series. American College of Rheumatology 2006, 290, Poster Presentation.

14. Casian A, Jayne D: Management of alveolar hemorrhage in lung vasculitides. Semin Respir Crit Care Med 2011, 32(3):355-45.

15. Casian A, Jayne D: Plasma exchange in the treatment of Wegener's granulomatosis, microscopic polyangitis, Churg-Strauss syndrome and renal limited vasculitis. Curr Opin Rheumatol 2011, 23(1):12-7.

16. Hiemstra TF, Walsh M, Mahr A, Savage CO, de Groot K, Hauser T, Neumann I, Tesar V, Wissing KM, Pagnoux C, Schmitt W, Jayne DR, European Vasculitis Study Group (EUVAS): Mycophenolate mofetil vs azathioprine for remission maintenance in antineutrophil cytoplasmic antibody-associated vasculitis: a randomized controlled trial. JAMA 2010 304(21):2381-8, Epub 2010 Nov 8

doi:10.1186/1546-0096-9-33

Cite this article as: Baird et al: Combination therapy with rituximab and cyclophosphamide in the treatment of anti-neutrophil cytoplasmic antibodies (ANCA) positive pulmonary hemorrhage: case report. Pediatric Rheumatology 2011 9:33.

\section{Submit your next manuscript to BioMed Central and take full advantage of:}

- Convenient online submission

- Thorough peer review

- No space constraints or color figure charges

- Immediate publication on acceptance

- Inclusion in PubMed, CAS, Scopus and Google Scholar

- Research which is freely available for redistribution

Submit your manuscript at www.biomedcentral.com/submit 